\title{
KNOWLEDGE DISCOVERY FOR DECISIONS MAKING IN NETWORK OF ENTERPRISES
}

\author{
Karaulova, T.; Kramarenko, S. \& Shevchenko, E.
}

Abstract: Rapid advances in technologies such as networks, database analysis techniques, and high speed processing helped the growing importance of organizational decision support systems (DSSs). Today's organizations invest in various knowledge management (KM) systems and tools to enable seamless integration of the constantly increasing volume and sources of information.

In the paper is offered approach for companies to integrating various sources of information and knowledge to enhance their decision-making process.

Key words: Knowledge management, Intelligent Decision Support system (IDSS), data mining
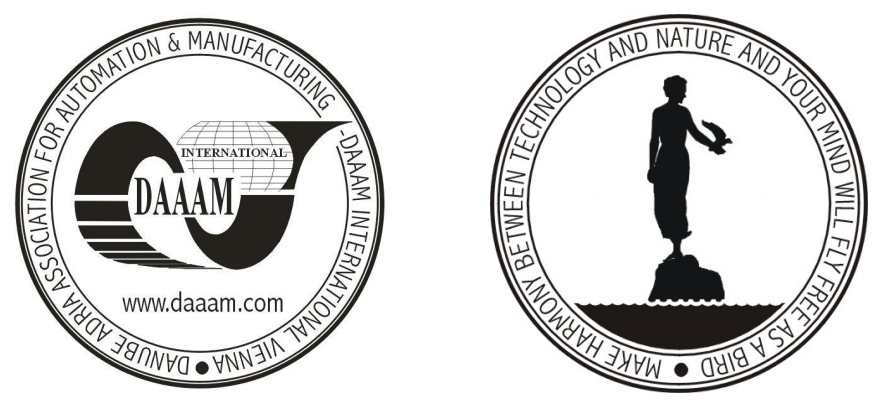

Authors' data: Ph.D. Karaulova, T[atyana]; M.Sc. Kramarenko, S[ergei]; M.Sc. Shevchenko, E[duard], Tallinn University of Technology, Department of Machinery, 19086 Tallinn, Estonia, tatjana.karaulova@ttu.ee, s.kramarenko@bsr.ee, eduard.shevtshenko@ttu.ee

This Publication has to be referred as: Karaulova, T.; Kramarenko, S. \& Shevchenko, E. (2007). Knowledge Discovery for Decisions Making in Network of Enterprises, Chapter 14 in DAAAM International Scientific Book 2007, B. Katalinic (Ed.), Published by DAAAM International, ISBN 3-901509-60-7, ISSN 1726-9687, Vienna, Austria

DOI: $10.2507 /$ daaam.scibook.2007.14 